\title{
АНАЛІТИЧНІ ДОСЛІДЖЕННЯ ІННОВАЦІЙНОГО ПІДХОДУ ДО УПРАВЛІННЯ КОМУНАЛЬНОГО НЕКОМЕРЦІЙНОГО ЗАКЛАДУ ОХОРОНИ ЗДОРОВ'Я
}

\author{
${ }^{1}$ ДВНЗ «Тернопільський державний медичний університет імені І. Я. Горбачевського МОЗ України», \\ м. Тернопіль, Україна \\ ${ }^{2}$ Харківський національний медичний університет, м. Харків, Україна
}

\begin{abstract}
Мета: показати нові можливості в управлінні комунальними некомерційними закладами охорони здоров'я, що 3'явилися після впровадження ресорми системи охорони здоров'я.

Матеріали і методи. Використано інституціональний, соціологічний та біхевіористський методи для аналізу нормативної бази, яка регламентує правову діяльність реформування системи охорони здоров'я в ракурсі інновацій в управлінні комунальними некомерційними закладами охорони здоров'я.

Результати. Показано ті основні моменти у вимогах до посади генерального директора комунального некомерційного закладу охорони здоров'я, які матимуть вирішальний вплив на результати діяльності закладу. Викладено застереження щодо ризиків, які можуть виникнути в процесі виконання функціональних обов'язків генеральним директором закладу. Показано синхронність та протистояння мети та місії комунального некомерційного закладу охорони здоров'я.
\end{abstract}

Висновки. За умов конкурсного відбору керівників комунальних некомерційних закладів охорони здоров'я варто вносити об'єктивні показники, які мають мінімальний вплив людського фрактора.

КЛЮЧОВІ СЛОВА: комунальні некомерційні заклади охорони здоров'я; керівник; генеральний директор.

Загальновідомо, що основна роль керівника - це привести організацію до мети. В системі охорони здоров'я основна мета організації, а це в основному заклад охорони здоров'я, це відтворення та збереження здоров'я населення. Мета, як бачимо, не одноразова, а постійнотривала в часі. Отож, головна роль керівника - це побудувати роботу організації так, щоб вона ефективно існувала якомога довший період часу.

Стів Джобс сказав: «Немає сенсу наймати тямущих людей, а потім вказувати, що їм робити. Ми наймаємо людей, щоб вони казали, що робити нам» [1]. Сьогодні в час реформи системи охорони здоров'я, коли призначення керівників лікувальних закладів змінюватиметься на їх обрання - ця цитата, як ніколи, є актуальною.

Мета дослідження: показати нові можливості в управлінні комунальними некомерційними закладами охорони здоров'я, що з'явилися після впровадження реформи системи охорони здоров'я.

Матеріали і методи. Використано інституціональний, соціологічний та біхевіористський методи для аналізу нормативної бази, яка регламентує правову діяльність реформування системи охорони здоров'я в ракурсі інновацій в управлінні комунальними некомерційними закладами охорони здоров'я.

Результати дослідження та їх обговорення. Процес реформування системи охорони здоров'я однозначно передбачає нові умови існування організацій охорони здоров'я, а відповідно, і вимагає акценту на нових ролях керівника. Ці нові ролі - це поєднання ролі керівника-конструктоpa, керівника-лідера та керівника-стратега. Кожне значення цих фрункцій може змінюватися залежно від ситуації, рівня розвитку організації, її місця у життєвому просторі тощо. Вони можуть поєднуватися у керівникові в найрізноманітніших пропорціях, знову ж таки, залежно від ситуації.

Реформовані організації системи охорони здоров'я повинні бути гнучкими і здатними до пристосування, органічно взаємодіяти 3 навколишнім світом і мати здатність реагувати на невизначеність та мінливі умови оточення.

Найважче випробування для керівників полягає в об'єднанні інтересів лікарів і організації. Така інтеграція вимагає нових моделей взаємних зв'язків «лікар - організація», нового осмислення цих зв'язків, більшої участі лікарів в управлінні та керуванні організаційною діяльністю. Без залучення лікарів неможливо вирішити такі проблеми, як управління вартістю, покращення якості медичної допомоги, підвищення продуктивності праці та використання ресурсів, а також здійснення стратегічного планування. Лікарі повинні відігравати ключову роль у фрормуванні політики, прийнятті рішень, розподілі ресурсів, а також у розробці та здійсненні стратегічних задумів. Звичайно, поява керованої медичної допомоги дає змогу організаціям і лікарям усвідомити, що вони

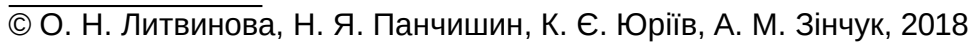


повинні діяти спільно, розділяючи ризик і розвиваючи механізм входження в ринок. Долі лікарів і організацій міцно переплилися, і в процесі еволюції ці зв'язки будуть набувати різних фрорм.

У сьогоднішніх складних умовах, коли переплелися проблеми економічної кризи в державі та фрінансування галузі зокрема, зниження нижче допустимого соціального рівня основної маси населення і демограсрічна криза, падіння моралі та зростання напруження між представниками різних медичних спеціальностей перед керівниками системи стоять досить складні проблеми, вирішення яких потребує неабияких здібностей і принципово нових знань та вмінь. Керівники повинні володіти комплексом знань та вмінь у сорері менеджменту та маркетингу, економіки та юриспруденції, бути в повному технічному та інформаційному всеозброєнні, бути добрими психологами, щоб володіти високим рівнем кваліфікації у веденні переговорів та врегулюванні конфлліктів.

Організації охорони здоров'я - це складні соціальні системи. Комунальне некомерційне підприємство самостійно визначає свою організаційну структуру, встановлює чисельність працівників і штатний розпис [2].

Отже, ще раз наголошуємо, що в нових умовах сьогодення управлінню охорони здоров'я потрібен фрахівець, який зможе добре організувати роботу для досягнення мети, що вимагає нових та відмінних від старих способів організації та управління системою охорони здоров'я. Найголовнішими 3 них на сьогодні є: управління ринком чи мережею послуг, що орієнтоване на охорону здоров'я населення; управління медичним обслуговуванням із виходом за межі організацій; активне управління якістю і постійне вдосконалення роботи.

Додаткові й досить суперечливі складнощі додає процесові управління охороною здоров'я ситуація, коли, з одного боку, керівники системи охорони здоров'я України, використовуючи одні й ті ж ресурси, покликані привести систему до її основної мети - зберегти здоров'я нації, a, з другого - забезпечити процвітання власних організацій. На жаль, ні того ні іншого в Україні сьогодні не маємо. І варто наголосити на тому, що основні акценти реформи охорони здоров'я виражено схиляють головних лікарів до пріоритетного відстоювання інтересів організації.

Останнє однозначно призведе до того, що зреформована в фрінансовому ракурсі система охорони здоров'я буде більше зацікавлена у наявності хвороби, аніж у її профрілактиці.

Проблеми економічної кризи в державі, зниження нижче допустимого прожиткового рівня основної маси населення, падіння моралі тісно між собою переплелися та призвели до зростання напруження як між окремими верстами населення, так і між представниками різних медичних спеціальностей. Розшарування суспільства на багатих та бідних (а якщо доходи нижче прожиткового рівня - то це жебраки) торкнулося і середовища медичних працівників. Можливість необмеженого збагачення одних і злидні інших не сприяє доброму мікроклімату в медичному закладі й безпосередньо негативно відображається на хворих. Жадоба збагачення у одних і злиденна безвихідь інших, з одного боку, і жебрацьке матеріальне становище більшості медичних працівників призводить до викривленої мотивації праці, що неухильно призводить до профранації з проявами якої ми все частіше сьогодні стикаємося.

Така ситуація ставить перед керівниками системи досить складні проблеми, вирішення яких потребує неабияких здібностей і принципово нових знань та вмінь. Керівники повинні володіти комплексом знань та вмінь у сорері менеджменту та маркетингу, економіки та юриспруденції, бути в повному технічному та інформаційному всеозброєнні, бути добрими психологами, щоб володіти високим рівнем кваліфікації у веденні переговорів та врегулюванні конфрліктів.

301 січня 2019 р. набирає чинності наказ МО3 від 31.10.2018 р. № 1977 «Зміни до Довідника кваліфікаційних характеристик професій працівників. Випуск 78 «Охорона здоров'я» [3].

Із 01 січня 2019 р. в Україні фрункції директора та медичного директора 303 будуть чітко розмежовані: директор закладу займатиметься питаннями господарської діяльності, а медичний директор - виключно питаннями медицини.

До 2022 р. обіймати посаду директора на конкурсній основі може претендент із гуманітарною освітою, правознавець, економіст, лікар, управлінець.

32022 р. претенденти, які не мають управлінської або менеджерської освіти у галузі знань «Управління та адміністрування» або «Публічне управління та адміністрування», повинні будуть додатково здобути її.

Із 2019 р. посаду медичного директора вводять у довідник медичних професій.

Генеральний директор, або директор закладу, займатиметься питаннями господарської діяльності, керуватиме виробничо-господарською та фрінансово-економічною діяльністю закладу. Відповідно до Довідника кваліфікаційних характеристик професій працівників [4] він займатиметься стратегічним плануванням, фрормуванням бюджету, координацією роботи закладу, аналізом економічної ефективності закладу, організацією роботи та ефрективної взаємодії всіх структурних підрозділів, забезпеченням залучення коштів на інвестиційні потреби закладу тощо.

Загальновідомо, що основна діяльність керівника полягає у доведенні керованої організації до визначеної мети. Якщо метою закладу охорони 
здоров'я за умов бюджетного фрінансування було виключно відтворення здоров'я пацієнтів, то за умов реформування системи, коли заклад стає окремою господарською одиницею на рівні 3 цією метою виступає інша мета - це економічна ефективність його діяльності. Специфріка системи охорони здоров'я полягає у тому, що ці дві мети не те, щоб суперечили одна одній, а швидше не сприяють їх досягненню. Відтворення здоров'я вимагає повсякчас більших фінансових затрат, а забезпечення зростання рентабельності за рахунок хворих людей, дуже обмеженого державного забезпечення та вишукування спонсорів дуже проблематичне.

Заклад охорони здоров'я провадить свою діяльність на підставі статуту (положення), який затверджує власник закладу (уповноважений ним орган). Керівник закладу охорони здоров'я незалежно від фрорми власності діє на базі вимог, які встановлює центральний орган виконавчої влади, що забезпечує фрормування державної політики у сорері охорони здоров'я $[5,6]$.

Необхідно, щоб під управлінням керівника діяльність закладу охорони здоров'я була ефективною, тобто, щоб за певний період часу організація безапеляційно виконувала свою місію і водночас мала позитивний економічний баланс. Враховуючи вищесказане, бачимо, що від керівника закладу охорони здоров'я вимагають здійснити складноздійсненне.

Проаналізуємо завдання та обов'язки генерального директора закладу охорони здоров'я 3 позицій аксіоми мотиваційних чинників: страху, переконання та вигоди.

Відповідно до кваліфрікаційної характеристики, генеральний директор закладу охорони здоров'я керує згідно 3 чинним законодавством виробничо-господарською та фрінансово-економічною діяльністю закладу охорони здоров'я, відповідає за фрінансово-господарські результати його діяльності. Щодо останньої позиції, то відповідальність за фрінансово-господарські результати діяльності закладу досить відносна. Конкретною вона є лише за грубі порушення фрінансових операцій, відповідно до чинного законодавства. Якщо ж фрінансово-господарські результати діяльності закладу є плачевними, але такими, що не виходять за рамки порушення закону, то ніякої відповідальності керівник не несе. Свідченням цього і є сотні убогих лікувальних закладів. Тому, за умов реформування управління закладом потрібно вносити зміни щодо оцінки роботи керівника, виходячи не з відсутності порушень, а з позицій досягнень і розвитку закладу. Відсутність такої мотивації призвела до того, що значна частина головних лікарів свою фрінансову майстерність спрямовувала не на розвиток керованого закладу, а на власне збагачення - свідченням цього є декларації головних лікарів. Якщо цей момент не враховувати при рефрормуванні, то ситуація не лише не зміниться, а ще більше ускладниться, оскільки генеральні директори тепер не відповідатимуть за лікувальний процес, а займатимуться виключно фрінансово-господарськими справами без відповідальності за розвиток закладу. Саме тому і спостерігаємо сьогодні масовий попит існуючих головних лікарів на освіту за напрямком «Менеджмент та адміністративне управління», бо саме цей диплом дасть їм можливість продовжити управлінську кар'єру, а умови проведення конкурсу сприяють діючим головним лікарям, а не новачкам. Організовує розробку та забезпечує реалізацію довгострокової стратегії розвитку закладу на основі потреб громади та ринкової ситуації. Без фрінансових гарантів ззовні (з боку держави чи органів місцевого самоврядування) потреби громади у здоров'ї та ринкову ситуацію урівноважити силами генерального директора закладу охорони здоров'я у більшості випадків не вдасться через неухильне зростання вартості медичної послуги, обмежені фрінансові ресурси та зростання потреб населення у якісній медичній допомозі. Заклад охорони здоров'я на чолі з генеральним директором не може впливати на фрактори ризику захворюваності, з одного боку, і не будучи комерційним прибутковим підприємством, не може мати зростаючі фрінансові потоки, з другого, не матиме можливостей урівноважувати попит населення на здоров'я та ринкові вимоги.

Мотиваційним чинником забезпечення реалізації довгострокової стратегії розвитку закладу повинна бути потенційна гарантія керівнику довгострокового обіймання посади. В іншому випадку - він буде зацікавлений вирішити свої потреби у короткостроковий період (поки при посаді).

Керівник закладу охорони здоров'я, який орієнтується на досягнення мети закладу, організовує формування та моніторинг виконання операційних планів як основного важеля. Розподілення та закріплення ресурсів, контроль за їх ефективним використанням та оцінка результативності діяльності повинні бути найголовнішими елементами його оперативної діяльності. Ці позиції однаковою мірою стосуються як генерального, так і медичного директора. Водночас необхідно відзначити, що ресурсне забезпечення буде прерогативою генерального директора, тоді як ефективність його використання більшою мірою залежатиме від медичного директора.

Генеральний директор забезпечує виконання усіх зобов'язань перед державним та місцевим бюджетами, державними позабюджетними соціальними фрондами, постачальниками, замовниками та кредиторами, а також виконання господарських і трудових договорів. Генеральний директор, за умови дотримання законодавства, 
може здійснювати лише такий обсяг зобов'язань, який підтримується фрінансуванням і залежить виключно від його повноважень. Якщо, для прикладу, державні чи місцеві бюджети не дотримуються зобов'язань перед закладом охорони здоров'я, то, відповідно, і заклад не може виконати свою частину зобов'язань. Тому доцільніше було б говорити, що генеральний директор забезпечує виконання тих зобов'язань, які підтримуються фрінансовим та правовим полем. Організовує роботу та ефективну взаємодію всіх структурних підрозділів, спрямовує їх діяльність на розвиток і вдосконалення 3 урахуванням соціальних та ринкових пріоритетів, підвищення ефективності роботи закладу охорони здоров'я, якості та конкурентоспроможності послуг, що надають, їх відповідність до стандартів надання медичної допомоги і задоволення потреб замовників і споживачів у відповідних видах медичної допомоги. Особливістю ринку медичних послуг є соціальна орієнтація, тому говорити про ринкові пріоритети, що являють собою максимізацію прибутків у випадку надання кваліфрікованих медичних послуг у жодному разі не можна.

Веде переговори 3 представниками власника закладу та замовниками щодо виконання планів та умов надання послуг.

Забезпечує залучення коштів на інвестиційні потреби закладу. Те, що заклад матиме інвестиційні потреби, не підлягає сумніву. Йдеться про те, що будь-який інвестор, формуючи портфель інвестицій, дбає насамперед про безпеку своїх інвестицій, їх ліквідність та високу прибутковість. Ринок медичних послуг за умов некомерційного підприємства повний потрясінь та небезпек для потенційного інвестора. Дещо більше гарантій в приватному бізнесі, хоч також не оракт. щодо ліквідності інвестицій або іншими словами здатності їх до швидкого і беззбиткового перетворення на готівку, то в закладах охорони здоров'я, які отримуватимуть кошти у 80 \% випадків із рук НСЗУ такі перетворення будуть дуже проблематичними. І, насамкінець, прибутковіть у комунальних некомерційних закладах буде забезпечена максимумом 20 \% платних медичних послуг, що саме по собі є мінімальними можливостями. А сьогодні майже усі заклади охорони здоров'я, відповідно до підписаного Президентом України Закону України «Про внесення змін до деяких законодавчих актів України щодо удосконалення законодавства з питань діяльності закладів охорони здоров'я» від 06.04.2017 р. № 2002-VIII, є комунальними некомерційними підприємствами [7]. Все вищенаведене говорить про те. що інвестор немає найменшої зацікавленості вкладати власні кошти у заклад, що не гарантує йому не лише прибутків, а й навіть гарантій збереженості. То ж генеральний директор швидше знайде меценатів чи спонсорів, аніж інвесторів.
Вживає заходи щодо забезпечення закладу охорони здоров'я кваліфрікованими працівниками, а також найкращого використання знань та досвіду працівників. Це один із найвідповідальніших обов'язків генерального директора. Саме від вміння залучати кваліфікованих фрахівців, плекати міцний, надійний колектив, створювати здоровий морально-психологічний клімат у колективі залежить продуктивність праці медперсоналу, його результативність, а відтак імідж організації та її успішність через активний попит на їх послуги.

Генеральний директор є наставником та забезпечує профресійний розвиток працівників. Вживає заходи щодо створення безпечних і сприятливих умов праці, дотримання вимог законодавства про охорону навколишнього середовища. Забезпечує розробку, укладання і виконання колективного договору. Генеральний директор відповідає за заходи щодо створення безпечних умов праці, що мало би передбачати засоби індивідуального захисту медичного персоналу. Ця позиція в українській медицині завжди була дуже погано розроблена і в основному лягала на плечі саме персоналу. Сумнівною є теза про доцільність організації генеральним директором розробки колективного договору. Цей процес має на меті забезпечити правові відносини в окремому колективі - у цьому випадку в закладі охорони здоров'я і передбачає як обов'язки, так і права усіх членів колективу, тож питання щодо поліпшення умов праці, життя і здоров'я, гарантії обов'язкового медичного страхування працівників закладу та їх сімей, а також інші питання соціального розвитку вирішуються трудовим колективом відповідно до законодавства.

Здійснює зовнішнє представництво закладу в адміністративних органах, засобах масової інформації тощо. Захищає майнові інтереси закладу охорони здоров'я в суді, органах державної влади та управління.

Забезпечує дотримання вимог трудового законодавства, створення на робочому місці в кожному структурному підрозділі умов праці відповідно до нормативно-правових актів, а також дотримання вимог законодавства щодо прав працівників у галузі охорони праці. Право на заробітну плату.

Забезпечує виконання вимог протипожежної безпеки. Затверджує правила внутрішнього трудового розпорядку, тривалість щоденної роботи та графріки змінності з дотриманням встановленої тривалості робочого тижня.

Вирішує питання щодо фрінансово-економічної та господарської діяльності закладу охорони здоров'я в межах наданих йому прав, доручає виконання окремих організаційно-господарських функцій іншим посадовим особам: заступникам директора, керівникам виробничих підрозділів, функціональних підрозділів закладу охорони 
здоров'я. Саме дирекція медзакладу фрормуватиме нові, внутрішні тарифні сітки, за якими працюватимуть лікарі, середній та молодший медичний персонал, залучатимуть інвестиції, розпоряджатимуться коштами, які зміг отримати медичний заклад за надання медпослуг населенню чи 3 інших джерел, наприклад оренда чи інвестиції, і ця позиція покладає практично повну відповідальність за діяльність закладу саме на генерального директора. Від його професійності та компетенції залежатиме стратегічне майбутнє закладу: розвиток чи занепад. У статутах комунальних некомерційних закладів останнім розділом є умови ліквідації закладу і головною умовою такої дії є заборгованість перед кредиторами.

Постановою Кабінету Міністрів від 27 грудня 2017 р. № 1094 затверджено «Порядок проведення конкурсу на зайняття посади керівника державного, комунального закладу охорони здоров'я» [8]. Враховуючи вагомість даних посад для комунальних некомерційних закладів охорони здоров'я, у руслі реформи системи охорони здоров'я запропоновано конкурсний відбір. Цей Порядок визначає механізм проведення конкурсу на обіймання посади керівника державного, комунального закладу охорони здоров'я.

Основною функціональною одиницею у виборі керівника закладу охорони здоров'я буде спеціальна конкурсна комісія. До її складу входять в однаковій кількості представники органу управління; трудового колективу відповідного закладу, обрані на загальних зборах трудового колективу; громадської ради органу управління або особи (за згодою), делеговані громадськими об'єднаннями з питань захисту інтересів громадян у сорері охорони здоров'я та/або у галузі запобігання корупції й антикорупційної діяльності (за умови реєстрації таких громадських об'єднань не менш як за два роки до дати рішення про проведення конкурсу) та погоджені громадською радою при органі управління - по одній особі від кожного громадського об'єднання.
Відповідно до Порядку, конкурсні комісії можуть бути створені на постійній основі, тоді представники трудового колективу залучаються до складу конкурсної комісії для кожного закладу окремо. Склад постійно діючої конкурсної комісії переглядають щороку.

Також варто відзначити, що особливості конкурсу для призначення керівників закладів, які провадять діяльність з надання лише первинної медичної допомоги, можуть визначатися відповідними уповноваженими виконавчими органами управління власника закладу охорони здоров'я (органи управління).

Умови проведення конкурсу вигідні існуючим керівникам, оскільки при викладених умовах третина складу комісії - це їх підлеглі, третина - ті, хто їх призначав попереднього разу і залишається третина членів громадських організацій, які почасти також $є$ достатньо заангажованими вже на етапі входження у громадську раду органу управління. Всі етапи конкурсу ґрунтуються на вирішальному людському фракторі, що є великою мірою суб'єктивним.

\section{Висновки}

За умов конкурсного відбору керівників комунальнихнекомерційнихзакладів охорони здоров'я потрібно налагодити систему об'єктивних показників, які мають мінімальний вплив людського фрактора. До таких можуть належати: медична та психологічна експертиза, результати тестових іспитів, формалізовані звіти про попередні результати управлінської діяльності, експертна (сліпа) оцінка програм майбутньої діяльності, аналіз декларації про доходи претендентів на посаду тощо.

Перспективи подальших досліджень полягають як у вивченні взаємовідносин між управлінськими рівнями державного управління та місцевого самоврядування, так і безпосередньо в комунальному некомерційному закладі охорони здоров'я.

\section{Список літератури}

1. Правила життя Стіва Джобса [Електронний ресурс]. - Режим доступу : https://www.jnsm.com.ua/h/PZ4/.

2. Господарський кодекс України 17 червня 2018 року [Електронний ресурс]. - Режим доступу : https://urist-ua.net/ кодекси/Господарський_Кодекс_України/.

3. Довідник кваліфікаційних характеристик професій працівників від 29.03.2002 р. № 117 [Електронний ресурс]. Охорона здоров'я. - Вип. 78. - Режим доступу : https://1med-vip.expertus.ua/\#/document/94/44995//.

4. Про внесення змін до Довідника кваліфікаційних характеристик професій працівників [Електронний ресурс] : наказ МОЗ від 31.10.2018 р. № 1977. - Охорона здоров'я. - Вип. 78. - Режим доступу : https://1med-vip.expertus.ua/\#I document/94/46321/dfascp74kz/?of=copy-9741d9b54f.

5. Основи законодавства України про охорону здоров'я [Електронний ресурс] : Закон України від 19.11.1992 р. № 2801-XII. - Режим доступу : https://1med-vip.expertus.ua/\#/document/94/46290.

6. Про внесення змін до деяких законодавчих актів України щодо удосконалення законодавства з питань діяльності закладів охорони здоров'я [Електронний ресурс] : Закон України від 06.04.2017 р. № 2002-VIII. - Режим доступу : http://zakon.rada.gov.ua/laws/show/2002-19.

7. Про затвердження Порядку проведення конкурсу на зайняття посади керівника державного, комунального закладу охорони здоров'я [Електронний ресурс] : Постанова Кабінету Міністрів України від 27 грудня 2017 р. № 1094. - Режим доступу : http://zakon.rada.gov.ua/laws/show/1094-2017-п\#n157. 


\section{Referens}

1. Pravyla zhyttia Stiva Dzhobsa [Steve Jobs's life rules]. Retrieved from: https://www.jnsm.com.ua/h/PZ4/ [in Ukrainian]. 2. Hospodarskyi kodeks Ukrainy 17 chervnia 2018 roku [The Economic Code of Ukraine, June 17, 2018]. Retrieved from: https://urist-ua.net/кодекси/ Господарський_Кодекс_України/ [in Ukrainian].

3. Dovidnyk kvalifikatsiinykh kharakterystyk profesii pratsivnykiv vid 29.03.2002 № 117. Vypusk 78 "Okhorona zdorovia" [Reference book of qualification characteristics of professions of workers from March 29, 2002 № 117. Issue 78 "Health care"]. Retrieved from: https://1med-vip.expertus.ua/\#/document/94/44995// [in Ukrainian].

4. Nakaz MOZ "Pro vnesennia zmin do Dovidnyka kvalifikatsiinykh kharakterystyk profesii pratsivnykiv. Vypusk 78 "Okhorona zdorovia" Publikatsiia Systemy "Expertus: Medzaklad" vid 31.10.2018 № 1977 [Order of the Ministry of Health of Ukraine "On amendments to the Directory of qualification characteristics of professions of workers. Publication 78 "Healthcare" Publication of the "Experts: Medicare" system from October 31, 2018, № 1977]. Retrieved from https://1medvip.expertus.ua/\#/document/94/46321/dfascp74kz/?of=copy-9741d9b54f [in Ukrainian].

5. Zakon Ukrainy "Osnovy zakonodavstva Ukrainy pro okhoronu zdorovia" vid 19.11.1992 № 2801-XII (ch. 6-7 st. 16 Zakonu) [Law of Ukraine "On the Basis of the Legislation of Ukraine on Health Care" of November 19, 1992, № 2801-XII (Part 6-7 of Article 16 on the Law of Ukraine)]. Retrieved from: https://1med-vip.expertus.ua/\#/document/94/46290 [in Ukrainian].

6. Zakon Ukrainy "Pro vnesennia zmin do deiakykh zakonodavchykh aktiv Ukrainy shchodo udoskonalennia zakonodavstva z pytan diialnosti zakladiv okhorony zdorovia" vid 06.04.2017 r. № 2002-VIII [The Law of Ukraine "On Amending Certain Legislative Acts of Ukraine Regarding Improvement of Legislation Regarding Activities of Health Care Institutions" dated April 6, 2017 № 2002-VIII]. Retrieved from: http://zakon.rada.gov.ua/laws/show/2002-19 [in Ukrainian].

7. Postanova Kabinetu Ministriv Ukrainy "Pro zatverdzhennia Poriadku provedennia konkursu na zainiattia posady kerivnyka derzhavnoho, komunalnoho zakladu okhorony zdorovia" vid 27 hrudnia 2017 r. № 1094. [Resolution of the Cabinet of Ministers of Ukraine "On Approval of the Procedure for conducting a competition for the position of Head of the State and Communal Healthcare Establishment" of December 27, 2017, № 1094]. Retrieved from: http://zakon.rada.gov. ua/laws/show/1094-2017-n\#n157 [in Ukrainian].

\section{АНАЛИТИЧЕСКИЕ ИССЛЕДОВАНИЯ ИННОВАЦИОННЫХ ПОДХОДОВ В УПРАВЛЕНИИ КОММУНАЛЬНОГО НЕКОММЕРЧЕСКОГО УЧРЕЖДЕНИЯ}

О. Н. Литвинова ${ }^{1}$, Н. Я. Панчишин ${ }^{1}$, Е. Е. Юриив ${ }^{1}$, А. Н. Зинчук ${ }^{2}$

${ }^{1}$ ГВУЗ «Тернопольский государственный медицинский университет имени И. Я. Горбачевского МЗ Украины»,

г. Тернополь, Украина

${ }^{2}$ Харьковский национальный медицинский университет, г. Харьков, Украина

Цель: показать новые возможности в управлении коммунальными некоммерческими учреждениями здравоохранения, появившиеся после введения реформы системы здравоохранения.

Материалы и методы. Использованы институциональный, социологический и бихевиористский методы для анализа нормативной базы, регламентирующей правовую деятельность реформирования системы здравоохранения в ракурсе инноваций в управлении коммунальными некоммерческими учреждениями здравоохранения.

Результаты. Показано те основные моменты в требованиях к должности генерального директора коммунального некоммерческого учреждения здравоохранения, которые будут иметь решающее влияние на результаты деятельности учреждения. Изложено предостережение о рисках, которые могут возникнуть в процессе выполнения фрункциональных обязанностей генеральным директором учреждения. Показано синхронность и противостояние цели и миссии коммунального некоммерческого учреждения здравоохранения.

Выводы. В условиях конкурсного отбора руководителей коммунальных некоммерческих учреждений здравоохранения необходимо вносить объективные показатели, которые имеют минимальное влияние человеческого фрактора.

КЛЮЧЕВЫЕ СЛОВА: коммунальные некоммерческие учреждения здравоохранения; руководитель; генеральный директор.

\section{ANALYTICAL RESEARCHES OF INNOVATIVE APPROACHES IN THE MANAGEMENT OF A COMMUNAL NON-COMMERCIAL INSTITUTION}

O. N. Lytvynova ${ }^{1}$, N. Y. Panchyshyn ${ }^{1}$, K. Y. Yuriiv ${ }^{1}$, A. M. Zinchuk ${ }^{2}$

${ }^{1}$ I. Horbachevsky Ternopil State Medical University, Ternopil, Ukraine

${ }^{2}$ Kharkiv National Medical University, Kharkiv, Ukraine

Purpose: to show new opportunities in the management of public non-profit health care institutions, which appeared after the introduction of health care reform.

Materials and Methods. The institutional, sociological and behavioral method was used to analyze the regulatory framework governing the legal activity of reforming the health care system in terms of innovations in the management of public non-profit health care institutions. 
Results. The main points are shown in the requirements for the position of the general director of the municipal non-profit health care institution, which will have a decisive influence on the final activity of the institution. There is a warning about the risks that may arise in the process of performing functional duties by the general director of the institution. The synchronicity and opposition of the goal and mission of the municipal non-profit health care institution are shown.

Conclusions. In the context of the competitive selection of managers of municipal non-profit health care institutions, it is necessary to introduce objective indicators that have minimal influence of the human factor.

KEY WORDS: municipal non-profit health care institutions; head; general director.

Рукопис надійшов до редакції 05.10.2018 p.

\section{Відомості про авторів:}

Литвинова Ольга Несторівна - доцент кафедри соціальної медицини, організації та економіки охорони здоров'я з медичною статистикою ДВНЗ «Тернопільський державний медичний університет імені І. Я. Горбачевського МОЗ України»; тел.: +38(0352) 52-72-33.

Панчишин Наталія Ярославівна - доцент кафедри соціальної медицини, організації та економіки охорони здоров'я з медичною статистикою ДВНЗ «Тернопільський державний медичний університет імені І. Я. Горбачевського МОЗ України»; тел.: +38(0352) 52-72-33.

Юріїв Катерина Євгенівна - старший викладач кафедри патологічної фрізіології ДВНЗ «Тернопільський державний медичний університет імені І. Я. Горбачевського МОЗ України»; тел.: +38(0352) 43-12-62.

Зінчук Андрій Миколайович - кандидат медичних наук, доцент кафедри громадського здоров'я та управління охороною здоров'я Харківського національного медичного університету; тел.: +38(057) 707-72-00. 